Raising the Dead 


\section{RAISING THE DEAD}

Readings of Death and (Black) Subjectivity

\section{SHARON PATRICIA HOLLAND}

Duke University Press Durham and London

2000 
(C) 2000 Duke University Press All rights reserved

Printed in the United States of America on acid-free paper

Designed by C. H. Westmoreland Typeset in Palatino with Antique Olive display

by Wilsted \& Taylor Publishing Services

Library of Congress Cataloging-in-Publication Data appear on the last

printed page of this book. 
TO ALL THOSE I HAVE KNOWN IN THE PLACE OF THE LIVING

\author{
Robert Edward “Flip" Holland \\ Theola Priscilla Green Martin \\ John L. Smith \\ Jesse Evans \\ Michael Scott \\ Vera Lewis \\ Alfonso Ortiz \\ My Beloved “Sula” Dog \\ Lora Romero
}


